Grażyna Ancyparowicz

Narodowy Bank Polski, Rada Polityki Pieniężnej

Górnoślaska Wyższa Szkota Handlowa

\title{
Programy Interwencyjne w Polityce Pieniężnej Eurosystemu
}

\section{INTERVENTION PROGRAMS IN THE MONETARY POLICY OF THE EUROSYSTEM}

\begin{abstract}
Niniejszy artykut przedstawia uwarunkowania prawne $i$ przesłanki tzw. luzowania ilościowego (quantitative easing, QE) w polityce pieniężnej Eurosystemu. Omówiono główne programy interwencyjnych zakupów dłużnych papierów wartościowych, wzmiankujac zwiazane z tymi programami ryzyka dla stabilności systemu finansowego, które moga zmaterializować się $w$ dalszej perspektywie. Podkreślono potrzebe statego monitorowania niestandardowych instrumentów finansowych stosowanych w krajach Eurolandu, tak aby polskie centralne instytucje finansowe rozporzqdzaty petnym instrumentarium przeciwdziałania niekorzystnym zjawiskom $w$ sferze krajowych finansów i gospodarki, które mogłyby zaistnieć i u nas w sytuacji kryzysowej o globalnym zasięgu. W badaniu zastosowano metodę analizy dokumentów Europejskiego Banku Centralnego (EBC) oraz wewnętrznych materiałów NBP dotyczqcych niestandardowych instrumentów polityki pieniężnej.
\end{abstract}

Słowa kluczowe: bank centralny, luzowanie ilościowe, duży program skupu aktywów JEL Codes: G01, G21, G28, H12

\section{Wstęp}

Tradycyjnie rozumiana polityka pieniężna polega na sygnalizowaniu pożądanej wysokości stopy procentowej i dostosowaniu bazy monetarnej do poziomu odpowiadającego tej wysokości. Banki centralne, w ramach przyjętej przez siebie strategii, pełnią misję stabilizacji siły nabywczej emitowanej przez siebie waluty, korzystając z szerokiego wachlarza instrumentów. Do bieżącego sterowania rynkiem międzybankowym służą zmiany krótkoterminowych stóp procentowych oraz podstawowe operacje otwartego rynku (rzadziej - operacje sterylizujące). Jednak tradycyjne strategie oraz instrumenty stabilizacji systemu finansowego zawiodły, gdy upadek wielkiego banku inwestycyjnego Lehman Brothers (15 września 2008 r.) podważył zaufanie do instytucji rynku finansowego. W odpowiedzi na drastyczne ograniczenie akcji kredytowej (credit crunch), Europejski Bank Centralny (podobnie jak wcześniej Bank Japonii, Bank Anglii oraz FED) podjął działania zwiększające ekspansywność polityki pieniężnej, stosując zarówno klasyczne jak i niestandardowe instrumenty polityki pieniężnej.

W obliczu narastającego ryzyka znacznego spowolnienia wzrostu gospodarczego na świecie i długotrwałego utrzymywania się inflacji poniżej celu uważanego za pożądany dla podtrzymania koniunktury $(2 \% \mathrm{r} / \mathrm{r})$, polityka zasilania przez bank 
centralny realnej sfery gospodarki narodowej przybrała charakter interwencyjny, a po uspokojeniu sytuacji na rynkach finansowych - antycykliczny. Po tym, jak wyczerpały się klasyczne narzędzia banku centralnego (bo podstawowe stopy procentowe osiagnęły wartość zerową lub ujemną), zastosowano instrumenty bezpośrednio zasilające w płynność rynek papierów dłużnych, a pośrednio - realną sferę gospodarki (Dudkiewicz B., 2016; Grosnal i in., 2016; Ancyparowicz, 2017, s. 11-20).

Celem niniejszego artykułu jest charakterystyka głównych instrumentów, które złożyły się na politykę luzowania ilościowego (quantitative easing - QE) realizowaną w Eurosystemie w latach 2012-2018. Tego rodzaju instrumenty polityki finansowej najwcześniej zastosowano w Japonii, potem w USA, a następnie w Unii Europejskiej, aby zwalczyć skutki kryzysu finansowego 2007-2009. Chociaż instrumenty te okazały się niezwykle pomocne $\mathrm{w}$ walce o zachowanie stabilności globalnego systemu finansowego i skutecznie pobudziły aktywność gospodarki w dobie pokryzysowej, ich efektywność stopniowo maleje; są to bowiem środki doraźne i nie zastąpią one koniecznej reformy globalnego systemu finansowego.

Doświadczenia krajów Eurolandu mogą być ważną przesłanką modyfikacji polityki pieniężnej w Polsce, gdyby kiedykolwiek wystąpiła potrzeba interwencji polskiego banku centralnego przy użyciu niestandardowych narzędzi polityki finansowej ${ }^{1}$. Również prywatne instytucje sektora finansowego, a także korporacje działające w sferze gospodarki realnej, powiązane z rynkami finansowymi poprzez kredyty czy emisje obligacji korporacyjnych, powinny być na bieżąco informowane o nowych, niestandardowych rozwiązaniach, koncepcjach i trendach na głównych rynkach finansowych współczesnego świata. Temu służy komunikacja z rynkiem, działalność wydawnicza i edukacyjna NBP.

\section{Skup obligacji skarbowych w Eurosystemie}

Traktat o funkcjonowaniu Unii Europejskiej w art. 123 stanowi: Zakazane jest udzielanie przez Europejski Bank Centralny lub banki centralne Państw Członkowskich, zwane dalej „krajowymi bankami centralnymi”, pożyczek na pokrycie deficytu lubjakichkolwiek innych kredytów instytucjom, organom lub jednostkom organizacyjnym Unii, rzadom centralnym, władzom regionalnym, lokalnym lub innym wtadzom publicznym, innym instytucjom lub przedsiębiorstwom publicznym Państw Członkowskich, jak również nabywanie bezpośrednio od nich przez Europejski Bank Centralny lub krajowe banki centralne ich papierów dlużnych. Regulacja ta została również ujęta w art. 21 Statutu ESBC/EBC. Tym niemniej, art. 18 ust. 1., tego Statutu określa sytuacje, w których norma ta nie obowiązuje: aby osiagnać cele ESBC $i$ wykonywać swe zadania, EBC i krajowe banki centralne moga dokonywać operacji na rynkach finansowych $w$ formie kupna i sprzedaży bezwarunkowej (outright).

\footnotetext{
${ }^{1}$ W Polsce występuje wysoka nadpłynność systemu bankowego, wywołana głównie silnym strumieniem napływu środków pomocowych z Unii Europejskiej. W tej sytuacji nie wystapiła dotychczas potrzeba podjęcia przez Narodowy Bank Centralny działań antykryzysowych o charakterze antycyklicznym, polegających na bezpośrednim zasilaniu w płynność krajowego rynku bankowego i pobudzaniu akcji kredytowej na rzecz sektora niefinansowego. Jednak, zgodnie z założeniami polityki pieniężnej, NBP może w określonych warunkach przeprowadzić emisję obligacji, zakup oraz sprzedaż papierów wartościowych na rynku wtórnym, włącznie z zakupem lub sprzedażą obligacji korporacyjnych (NBP, 2018, s. 8).
} 
Spośród dotychczas wykorzystywanych antycyklicznych instrumentów polityki pieniężnej, zastosowanych $\mathrm{w}$ reakcji na kryzys przez Europejski System Banków Centralnych (ESBC) można wymienić: zerowe i ujemne stopy procentowe, skup obligacji skarbowych oraz zakupy (spełniających wysokie kryteria bezpieczeństwa) obligacji korporacyjnych. Transakcje te przeprowadzane były początkowo wyłącznie na rynku wtórnym, ale później także na rynku pierwotnym przez banki centralne Eurosystemu (tabela 1). Każdy z interwencyjnych programów skupu instrumentów finansowych zasilał $\mathrm{w}$ płynność realną sferę gospodarki, choć czynił to $\mathrm{w}$ charakterystyczny dla siebie sposób.

Tabela 1. Uwarunkowania makroekonomiczne w momencie wprowadzenia skupu obligacji skarbowych przez EBC i inne wybrane banki centralne

\begin{tabular}{|l|r|r|r|r|r|}
\hline \multicolumn{1}{|c|}{ Wyszczególnienie } & Japonia & $\begin{array}{c}\text { Wielka } \\
\text { Brytania }\end{array}$ & $\begin{array}{c}\text { Stany } \\
\text { Zjednoczone }\end{array}$ & Strefa euro & Szwecja \\
\hline $\begin{array}{l}\text { Data ogłoszenia } \\
\text { skupu obligacji } \\
\text { skarbowych }\end{array}$ & $2008-12-19$ & $2009-03-05$ & $2009-03-18$ & $2015-01-22$ & $2015-02-12$ \\
\hline $\begin{array}{l}\text { Referencyjna stopa } \\
\text { procentowa banku } \\
\text { centralnego }\end{array}$ & 0,10 & 0,50 & $0,00-0,25$ & 0,05 & $-0,10$ \\
\hline $\begin{array}{l}\text { Dynamika PKB } \\
\text { (realny przyrost } \\
\text { w stosunku do } \\
\text { poprzedniego roku, } \\
\text { w \%) }\end{array}$ & $-3,7$ & $-5,9$ & $-3,5$ & 1,8 & 3,6 \\
\hline $\begin{array}{l}\text { Inflacja (zmiany cen } \\
\text { w stosunku do roku } \\
\text { poprzedniego, w \%) }\end{array}$ & 0,4 & 2,9 & $-0,4$ & $-0,6$ & 0,1 \\
\hline
\end{tabular}

Źródło: Niestandardowe działania w zakresie polityki pieniężnej stosowane przez wybrane banki centralne, materiały wewnętrzne NBP, Warszawa, 2018.

Strategia Eurosystemu w reakcji na kryzys i uporczywą recesję w krajach Eurolandu była realizowana w dwu etapach. Pierwszy etap rozpoczął się 9 października 2008 r., a zamknął komunikatem po posiedzeniu Rady Prezesów 4 czerwca 2014 r.; drugi etap został zainicjowany kilka tygodni później i trwał do końca 2018 r. Działalność EBC prowadzona w latach 2008-2014 była zorientowana przede wszystkim na zwiększenie płynności w systemie bankowym i stosowanie instrumentów motywujących banki do zwiększenia akcji kredytowej (Enhanced Credit Support Programme). W tym okresie, w ramach pomocy dla najbardziej dotkniętych kryzysem krajów strefy euro, prowadzono na rynku wtórnym zakupy zabezpieczonych obligacji rządowych (CBPP3) i skup papierów wartościowych zabezpieczonych aktywami (ABSPP). W szczególności, z dniem 10 maja 2010 r. wdrożono program Security Market Purchase (SMP), który doprowadził to tak silnego wzrostu płynności w Eurosystemie, że EBC musiał uciec się do operacji sterylizujących ${ }^{2}$. Z dniem 6 września 2012 r. ruszył program - Outright Monetary Trasactions (OMT), formalnie realizowany do lipca 2014 r., który okazał się zbyt restrykcyjny, aby (pomimo znacznej

\footnotetext{
${ }^{2}$ Ten wzrost płynności utrzymywał się w następnych latach i był związany głównie z nabywaniem papierów wartościowych w ramach program skupu aktywów sektora publicznego (PSPP). Na dzień 13 lipca $2018 \mathrm{r}$. wartość obligacji skupionych w ramach SMP wyniosła $82882 \mathrm{mln}$ EUR (NBP, 2018a, s. 81-82).
} 
obniżki rentowności skarbowych papierów wartościowych) mógł stymulować akcję kredytową. Rok wcześniej, EBC siegnął po inne niestandardowe narzędzie określane mianem forward guidance, kiedy to oficjalnie zobowiązał się do utrzymywania przez dłuższy czas stóp procentowych na rekordowo niskim poziomie (EBC, 2017, s. A 4-A 6).

Działaniami uzupełniającymi $\mathrm{w}$ stosunku do interwencyjnego skupu papierów rządowych przez banki centralne stały się programy czasowego pożyczania aktywów (securities lending), które służyły poprawie płynności wybranych segmentów rynku papierów wartościowych. Prekursorem tej formy interwencji na rynku finansowym był FED, który operacje o tym charakterze prowadził już w latach 60. ubiegłego wieku. Doświadczenia z tego okresu wykorzystał później dla odbudowy zaufania do rynku finansowego po kryzysie subprime, tym skuteczniej, że już wcześniej prowadził politykę pieniężną opartą na przeprowadzaniu transakcji bezwarunkowego kupna aktywów z wykorzystaniem papierów emitowanych przez rząd federalny. Operacje pożyczania aktywów (securities lending) prowadzone są również przez ESBC, z zasady w formie przetargów, a polegają one na wymianie na termin $\mathrm{O} / \mathrm{N}$ wybranych papierów wartościowych (m.in. bonów, obligacji oraz papierów wartościowych indeksowanych do wskaźnika inflacji).

W warunkach uporczywie niskiej inflacji EBC dążył do wywołania efektu synergicznego w wyniku współdziałania polityki monetarnej, fiskalnej i strukturalnej. W szczególności, możliwość interwencyjnych zakupów dużych pakietów obligacji skarbowych przez bank centralny ułatwiała zarządzanie finansami państwa, bowiem można było w ten sposób zwiększać popyt na rządowe papiery wartościowe, co obniżało rentowność tych walorów i w efekcie prowadziło do stopniowego obniżania kosztów obsługi długu publicznego. Tym samym zwiększała się zdolność ministra finansów do pozyskania efektywnego kosztowo, rynkowego finansowania bieżącego deficytu budżetowego i obniżenia kosztów spłaty wymagalnych zobowiązań.

Banki sprzedające EBC skarbowe papiery wartościowe mogły wykorzystać wykreowany w ten sposób pieniądz do nabywania innych aktywów finansowych, a także do rozszerzenia akcji kredytowej na rzecz realnej sfery gospodarki. Ta polityka niesie jednak ryzyko, jeżeli bowiem skala skupu przez bank centralny obligacji emitowanych przez ministra finansów przybiera zbyt duże rozmiary, to $w$ końcu zniechęca inwestorów, obniżając popyt na skarbowe papiery wartościowe. Dlatego też EBC, kontynuując interwencyjny skup obligacji rządowych, w 2016 r. sięgnął również po inne niestandardowe instrumenty polityki pieniężnej ${ }^{3}$.

\section{Skup obligacji komercyjnych przez banki Eurosystemu}

Na początku 2014 r. dynamika kurczenia się akcji kredytowej w krajach strefy euro zaczęła przekraczać 2\% miesięcznie, bowiem lokowanie środków w bankach centralnych spowodowało, iż nadpłynność w sektorze bankowym została zredukowana

\footnotetext{
${ }^{3}$ W grudniu 2018 r. Europejski Bank Centralny kończył swój program zakupu aktywów, a amerykańska Rezerwa Federalna kontynuowała cykl podnoszenia stóp procentowych, jednocześnie zmniejszając swój bilans. Wielu obserwatorom wydawało się wówczas, że rok 2019 upłynie pod znakiem dalszego zacieśniania polityki pieniężnej na świecie, ale w obliczu spowolnienia dynamiki PKB i groźby recesji, od listopada 2019 r. EBC powrócił na ścieżkę luzowania monetarnego. W ślad za nimi politykę pieniężną złagodziło także wiele innych banków centralnych na świecie.
} 
w ciagu dwu lat dziesięciokrotnie (do 80 mld EUR), a kurs EUR/USD zbliżył się do rekordowo wysokiego poziomu $(1,40)$. W związku z tym EBC od lipca $2014 \mathrm{r}$. zaniechał operacji sterylizujących, wprowadził ujemną stope procentową od środków utrzymywanych przez banki na rachunku bieżącym banku centralnego oraz w depozycie, a także uruchomił pożyczki (targeted longer-term refinancing operations - TLTRO) zaprojektowane $\mathrm{w}$ taki sposób, aby stanowiły one bodziec do zwiększenia akcji kredytowej dla sektora niefinansowego.

W komunikacie z 21 kwietnia 2016 r. Rada EBC określiła kryteria kwalifikowalności aktywów będących przedmiotem skupu w ramach Corporate Sector Purchase Programme - CSPP (Guideline EU 2015/510) oraz poinformowała, że skupione obligacje korporacyjne będą oferowane $\mathrm{w}$ ramach programu securities lending ${ }^{4}$. W dniu 1 czerwca 2016 r. zapadła Decyzja (EBC/2016/26) w sprawie uruchomienia programu zakupu komercyjnych papierów wartościowych posiadających rating kredytowy (również na rynku pierwotnym, z wyłączeniem obligacji emitowanych przez podmioty zaliczane do sektora publicznego) $)^{5}$. Decyzję tę poprzedziło następujące oświadczenie: chociaz EBC podziela poglad, że świadomość problemów zwiqzanych ze środowiskiem, wraz z zachowaniem etycznym i spolecznie odpowiedzialnym, jest ważna dla spoleczeństwa, to jednak decydenci polityczni (w pierwszym rzędzie) musza uzgodnić, zdefiniować i promować odpowiednie polityki iśrodki. Nie jest jednak możliwe umieszczenie ich $w$ programie skupu aktywów na duża skale, który jest realizowany jako tymczasowy środek polityki pieniężnej w stosunkowo krótkim czasie, [bowiem] ograniczyłoby to skuteczność APP w jej wkladzie w wypetnianie mandatu EBC w zakresie utrzymania stabilności cen (EBC, 2017a).

Tydzień później program skupu obligacji korporacyjnych wszedł w fazę realizacji, za pośrednictwem banków spełniających kryteria kwalifikacji Eurosystemu (tablica 2).

Tablica 2. Banki centralne Eurosystemu uczestniczące w CSPP

\begin{tabular}{|l|l|}
\hline \multicolumn{1}{|c|}{ Krajowy bank centralny } & \multicolumn{1}{c|}{ Kraj pochodzenie skupowanej obligacji korporacyjnej } \\
\hline Banque Nationale de Belgique & $\begin{array}{l}\text { Belgia, Cypr, Grecja, Holandia, Luksemburg, Malta, Portugalia, } \\
\text { Słowacja, Słowenia }\end{array}$ \\
\hline Deutsche Bundesbank & Niemcy, Holandia \\
\hline Banco de Espana & Hiszpania, Holandia \\
\hline Suomen Pankki & Austria, Estonia, Finlandia, Irlandia, Litwa, Łotwa \\
\hline Banque de France & Francja \\
\hline Banco d'Italia & Holandia, Włochy \\
\hline
\end{tabular}

Źródło: NBP, 2018 s. 89.

\footnotetext{
${ }^{4}$ Warto przypomnieć, że papiery emitowane przez sektor prywatny (głównie obligacje) zostały włączone do katalogu instrumentów polityki pieniężnej w strefie euro na podstawie art. 2 ust. 2 Decyzji Rady Prezesów EBC nr 415/98 z 29 czerwca 1998 r. w sprawie konsultacji Europejskiego Banku Centralnego udzielanych władzom krajowym $w$ sprawie projektów przepisów prawnych $(98 / 415 / \mathrm{WE})$.

${ }^{5}$ Rada Prezesów EBC już wcześniej wyróżniła takie kryteria oceny emitenta i jego papierów dłużnych jak: okres pozostający do zapadalności obligacji w momencie skupu od 6 miesięcy do 30 lat i 364 dni, waluta emisji - EUR, , miejsce emisji obligacji - kraje strefy euro oraz rating kredytowy przyznany przynajmniej przez jedną agencję ratingową na poziomie inwestycyjnym. Warto odnotować, że rating kredytowy na poziomie inwestycyjnym odnosi się do emitenta/instrumentów dłużnych; według Fitch Ratings oraz S\&P poziom inwestycyjny określany jest w skali od AAA do BBB- (lub odpowiedniej w przypadku innej agencji ratingowej).
} 
Skup obligacji korporacyjnych może być realizowany przy wykorzystaniu platformy elektronicznej lub bezpośrednio w kontakcie banku centralnego z kontrahentem, a jego beneficjentami są - co do zasady - przedsiębiorstwa nie korzystające $\mathrm{z}$ finansowania na rynku kapitałowym. Przyjęto bowiem założenie, że tendencje występujące na rynkach kapitałowych mają przełożenie (spillover) także na to, co się dzieje na rynkach kredytowych ${ }^{6}$. Ocena efektywności programu skupu komercyjnych papierów wartościowych dokonywana jest przez EBC na podstawie następujących kryteriów: wpływu na koszty finansowania korporacji, wpływu na emisję nowych obligacji korporacyjnych oraz wpływu na strukturę kapitałową emitenta i korporacji nie objętych programem (EBC, 2018).

Tabela 3. Struktura zakupionych przez Eurosystem obligacji korporacyjnych

\begin{tabular}{|c|c|c|}
\hline Wyszczególnienie & $\begin{array}{c}\text { Obligacje spełniające kryteria } \\
\text { CSPP }\end{array}$ & $\begin{array}{l}\text { Obligacje skupione w ramach } \\
\text { CSPP }\end{array}$ \\
\hline Rating AA & $13 \%$ & $11 \%$ \\
\hline Rating A & $44 \%$ & $43 \%$ \\
\hline Rating BBB & $43 \%$ & $46 \%$ \\
\hline \multicolumn{3}{|c|}{ Kraj/region } \\
\hline Francja & $31 \%$ & $30 \%$ \\
\hline Niemcy & $25 \%$ & $25 \%$ \\
\hline Włochy & $12 \%$ & $12 \%$ \\
\hline Hiszpania & $9 \%$ & $10 \%$ \\
\hline Holandia & $5 \%$ & $6 \%$ \\
\hline Belgia & $5 \%$ & $5 \%$ \\
\hline Szwajcaria & $3 \%$ & $4 \%$ \\
\hline Inne kraje Eurolandu & $6 \%$ & $6 \%$ \\
\hline Kraje spoza strefy euro & $4 \%$ & $3 \%$ \\
\hline \multicolumn{3}{|c|}{ Sektor gospodarki } \\
\hline Działalność usługowa & $17 \%$ & $15 \%$ \\
\hline Infrastruktura i transport & $13 \%$ & $11 \%$ \\
\hline Przemysł samochodowy & $10 \%$ & $9 \%$ \\
\hline Telekomunikacja & $8 \%$ & $9 \%$ \\
\hline Energia & $7 \%$ & $6 \%$ \\
\hline Nieruchomości & $7 \%$ & $6 \%$ \\
\hline Budownictwo & $5 \%$ & $6 \%$ \\
\hline Napoje & $4 \%$ & $6 \%$ \\
\hline Technologia & $5 \%$ & $5 \%$ \\
\hline Przemysł medyczny & $5 \%$ & $5 \%$ \\
\hline Chemia & $4 \%$ & $5 \%$ \\
\hline Żywność & $3 \%$ & $4 \%$ \\
\hline Ubezpieczenia & $3 \%$ & $3 \%$ \\
\hline Pozostałe sektory & $9 \%$ & $9 \%$ \\
\hline
\end{tabular}

Źródło: NBP, 2018, s. 95-96.

Do 31 grudnia 2017 r. nominowane w EUR papiery wartościowe nabyte w ramach wszystkich programów interwencyjnych osiagnęly wartość 228,4 mld EUR i stanowiły $55 \%$ aktywów ogółem EBC (wykres 1). Według publikowanych danych, dostępnych

\footnotetext{
${ }^{6}$ Luzowanie ilościowe realizowane w ramach polityki pieniężnej banku centralnego nie zwiększa majątku banków komercyjnych, a jedynie zmienia strukturę ich bilansu, zwiększając w nim udział aktywów płynnych (Bernanke, 2016).
} 
w momencie pisania niniejszego artykułu, do 6 lipca 2018 r. Eurosystem nabył (łącznie) obligacje korporacyjne o różnych terminach zapadalności, pochodzące ze 1154 różnych emisji (zagregowane informacje o ilościowej strukturze tego portfela zawiera tabela 3 ). W ujęciu ilościowym, ponad połowa tego portfela przypadała na 46 spółek. Najwięcej, bo aż 30 skupionych serii obligacji korporacyjnych było wyemitowanych przez niemiecki koncern Daimler, na drugim miejscu wystapiło francusko-holenderskie przedsiębiorstwo Unibail-Rodamco działające na rynku nieruchomości komercyjnych, natomiast firmy o charakterze strategicznym (na przykład Airbus Group Finance B. V.) zajmowały w tej statystyce odległe pozycje (choć z nieoficjalnych doniesień prasowych wiadomo, że w ujęciu wartościowym były to transakcje na wielką skalę). Wystapiły również przypadki nagłej sprzedaży korporacyjnych obligacji, które wcześniej nabył Eurosystem. Przykładem są tu m.in. obligacje wyemitowane przez brytyjski koncern Glencore, południowo-afrykański oddział koncernu Steinhoff Europe AG, a także obligacje firm nie spełniające warunków programu (NBP, 2018, s. 92-96).

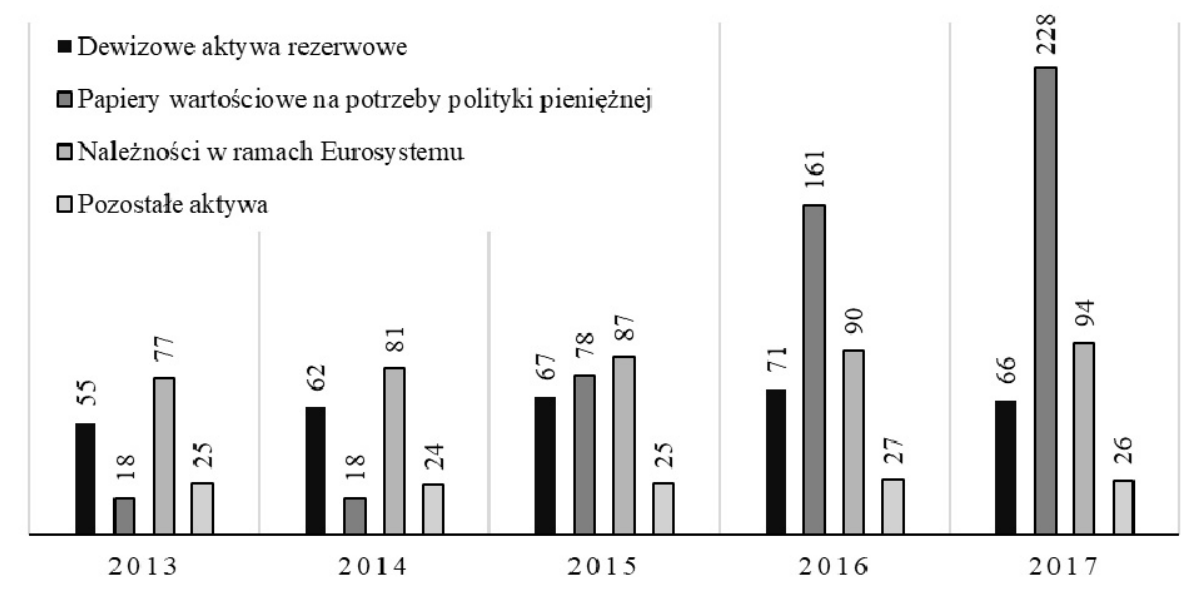

Wykres 1. Aktywa EBC, stan na 31. grudnia 2017, w mld EUR Źródło: EBC, 2017, s. 5 A

$\mathrm{W}$ związku $\mathrm{z}$ uruchomieniem zakupów obligacji korporacyjnych $\mathrm{w}$ ramach programu PSPP, w ostatnich dwu latach - stosunku do lat poprzednich - nastapiła wyraźna zmiana struktury portfela instrumentów wykorzystywanych na potrzeby polityki pieniężnej (EBC 2017, s. A 6). Zmniejszył się bowiem udział rządowych papierów wartościowym na rzecz wzrostu udziału obligacji korporacyjnych (wykres 2). 


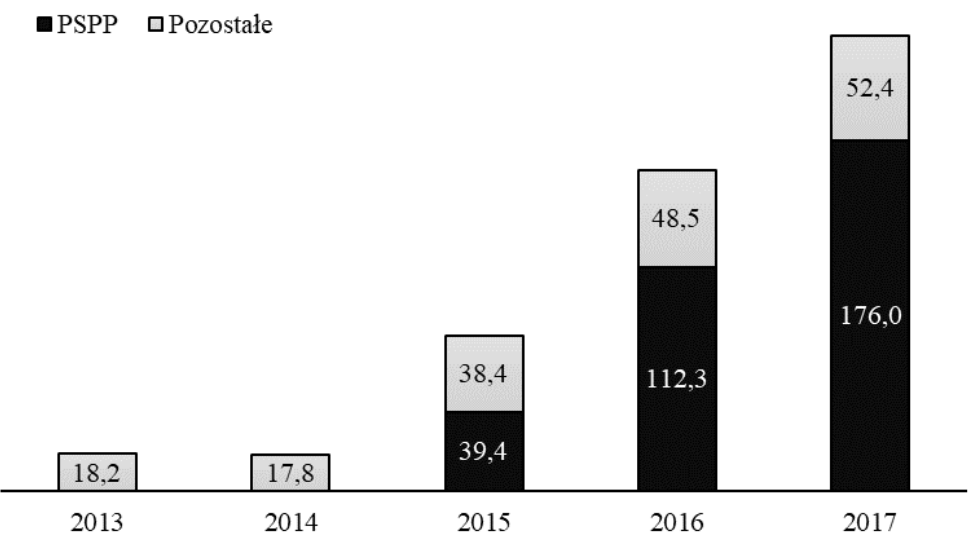

Wykres 2. Papiery wartościowe w portfelu EBC utrzymywane na potrzeby polityki pieniężnej, w mld EUR Źródło:, EBC, 2017, s A 6.

EBC dokonując ewaluacji polityki pieniężnej pozytywnie ocenił ten program, akcentując istotne zmniejszenie spreadów między rynkiem terminowym a kasowym, a także pozytywne tendencje $w$ innych obszarach rynku finansowego. Zwiększenie emisji obligacji korporacyjnych (przede wszystkim we Francji i Holandii) wywołało przesunięcie $\mathrm{w}$ strukturze finansowania działalności przedsiębiorstw niefinansowych, polegające na relatywnym spadku udziału kredytów zaciaganych w bankach komercyjnych przez firmy działajace w sferze gospodarki realnej. Dokonało się to, nie tyle ze względu na ograniczenia akcji kredytowej przez sektor bankowy, ile z uwagi na wzrost emisji własnych obligacji przedsiębiorstw ważnych dla gospodarki danego kraju, a także gospodarki całej Unii Europejskiej. Zaobserwowano także, iż wzrost zaangażowania rynku kapitałowego w finansowanie działalności wielkich korporacji, zachęca banki komercyjne do finansowania małych i średnich przedsiębiorstw, co przejawia się ułatwieniami dostępu do kredytów dla tej grupy klientów (EBC, 2018).

Rada Prezesów EBC nie określiła docelowej wartości wolumenu zakupów, a jedynie $\mathrm{w}$ komunikacie $\mathrm{z}$ dnia 26 października 2017 r. powiadomiła, że skup komercyjnych papierów dłużnych będzie prowadzony przynajmniej do końca września 2018 r. Termin ten właśnie mijał, gdy Rada Prezesów EBC oświadczyła, że „będzie kontynuować zakupy netto $\mathrm{w}$ ramach programu skupu aktywów (APP) na nowym poziomie $15 \mathrm{mld}$ euro miesięcznie do końca grudnia $2018 \mathrm{r}$. i przewiduje, iż jeśli średniookresowe perspektywy inflacji znajdą potwierdzenie w aktualnych danych, zakupy zostaną zakończone" (EBC, 2018).

Deklaracja ta pojawiła się w czasie, gdy w opinii większości analityków koniunktura gospodarcza w Eurolandzie ulegała ochłodzeniu, a wskaźniki wyprzedzające sugerowały kontynuację trendu spadkowego (NBP, 2018b, s. 9-20). Dlatego, już rok temu, większość obserwatorów przewidywała, że EBC najprawdopodobniej tylko zmniejszy skalę interwencyjnego skupu aktywów, ale po raz kolejny odroczy ostateczny termin zamknięcia programu APP i innych programów interwencyjnych przynajmniej do końca roku. Tak się stało. W ślad za tym nie nastapiła redukcja bilansu, bowiem EBC reinwestował spłaty kapitału po zakończeniu QE, 
chociaż przez pierwsze dziesięć miesięcy 2019 r. nie prowadził skupu aktywów na rynku pierwotnym.

Interwencyjna polityka pieniężna EBC budziła kontrowersje wewnątrz Rady Zarządzającej tego banku; było to nieuniknione. Strefa euro jest zbiorem gospodarek, które znacznie różnią się między sobą nie tylko pod względem bieżącej sytuacji koniunkturalnej, ale także uwarunkowań strukturalnych, takich jak poziom PKB per capita, poziom zadłużenia, skłonność do oszczędzania czy preferencje społeczne co do wysokości stóp procentowych. Pozostaje otwartym pytanie, kto najwięcej skorzysta na reinwestycjach papierów dłużnych, czy i jak zmienią się udziały poszczególnych państw Eurolandu w tzw. kluczu kapitałowym, według którego działa EBC skupując aktywa. Odejście od dotychczasowych zasad preferowałoby kraje ekonomicznie i finansowo mocniejsze, penalizując słabsze (przede wszystkim Włochy i Grecję), a to z pewnością nie pomoże tym gospodarkom, które najbardziej potrzebują wsparcia. Po ostatnim globalnym kryzysie finansowym pozostał „gorzki smak zawiedzionego zaufania i zerwanego paktu między finansami, gospodarką i społeczeństwem. (...) Taka napięta atmosfera skłania do wydawania uproszczonych ocen moralnych i etycznych" (Dembinski P. 2017, s. 10).

W odpowiedzi na te psychospołeczne wyzwania, Europejski Bank Centralny ponownie ogłosił (we wrześniu 2019 r.) cały pakiet działań zmierzających do złagodzenia warunków monetarnych, w szczególności: obniżył stopę depozytową z minus $0,4 \%$ do minus $0,5 \%$, jednocześnie sygnalizując utrzymywanie ujemnych stóp w dłuższym okresie, a nawet możliwość dalszych obniżek. Równocześnie wprowadził dwustopniowy system oprocentowania nadwyżkowych rezerw banków komercyjnych (tzw. tiering), który ma ograniczać negatywny wpływ ujemnej stopy depozytowej na wyniki banków, a ostatecznie na akcję kredytową. Wprowadzając to rozwiązanie de facto zwiększono możliwość dalszego obniżania stopy depozytowej w przyszłości. Ponadto EBC wznowił program skupu aktywów (po 20 mld euro miesięcznie) i to bez wyraźnego nakreślania granicznego terminu jego realizacji, zaś Rada Prezesów EBC złagodziła warunki długoterminowych operacji płynnościowych (TLTRO) polegających na udzielaniu refinansowania bankom komercyjnym, pod warunkiem zwiększenia przez nie akcji kredytowej.

\section{Zakończenie}

Każda decyzja $\mathrm{w}$ polityce pieniężnej wiąże się $\mathrm{z}$ możliwością wystąpienia efektów ubocznych, które ex ante trudno przewidzieć i ocenić. Jednakże, na podstawie dotychczasowych danych statystycznych i prognoz, można sformułować wniosek, że niekonwencjonalna polityka pieniężna EBC realizowana w reakcji na kryzys lat 20072009 dość skutecznie neutralizowała negatywne skutki załamania rynków finansowych w pierwszej fazie kryzysu i ułatwiła przełamanie recesji. Powrót gospodarki europejskiej na ścieżkę zrównoważonego wzrostu okazał się jednak nietrwały, w gospodarce Niemiec i mniej zamożnych krajów strefy euro pojawiają się ostatnio tendencje stagnacyjne, które mogą mieć trwały charakter, biorąc pod uwagę skalę i synchronizację globalnego pogorszenia koniunktury. Ryzyko pogłębienia lub utrwalenia stagnacji $\mathrm{w}$ warunkach niskiej inflacji ocenia się za poważne. W tej złożonej sytuacji, główne banki centralne, w tym EBC nie miały innego wyjścia, niż powrót na ścieżkę luzowania ilościowego, choć 
- z oczywistych względów - w skali znacznie skromniejszej niż przez laty, $\mathrm{z}$ wykorzystaniem zarówno pozytywnych jak i negatywnych doświadczeń z tamtego trudnego okresu.

Obok doraźnych i średniookresowych korzyści, polityka luzowania ilościowego niesie długofalowe ryzyka, którym zapewne trzeba będzie sprostać w bliżej nieokreślonej przyszłości. Zwracali na to uwagę ekonomiści już w pierwszych latach stosowania niestandardowych instrumentów, które posłużyły do luzowania ilościowego w polityce pieniężnej. W szczególności zwracano uwagę na następujące zagrożenia: po pierwsze, niestandardowe instrumenty polityki pieniężnej opóźniają reformę systemu finansów publicznych (Roubini i Mihm, 2010), po drugie - powodują nieuzasadnioną aprecjację walut narodowych (Stiglitz 2012, s. 37-39), po trzecie - generują gwałtowny przyrost agregatów pieniężnych na globalnych rynkach finansowych (Taylor, 2012, s. 19, Bernanke, 2012; Goodhart i Ashworth, 2012, s. 640-670).

Eksperymenty $\mathrm{w}$ ramach Eurosystemu przeprowadzane w obszarze polityki pieniężnej były i są uważnie obserwowane przez Narodowy Bank Polski. NBP jako uczestnik Europejskiego Systemu Banków Centralnych, zwraca baczną uwagę na to, by agendy analityczne i gremia decyzyjne miały pełną, aktualną wiedzę o światowych trendach w dziedzinie finansów. W „Założeniach Polityki Pieniężnej na rok 2020.” przewidziano zastosowanie niekonwencjonalnych instrumentów polityki pieniężnej ${ }^{7}$, jednak nic nie wskazuje na to, aby trzeba było po nie sięgać w dającej się przewidzieć perspektywie czasowej (Glapiński, 2019).

\section{Literatura}

Ancyparowicz G. (2017), Wybrane aspekty strategii celu inflacyjnego w teorii i praktyce banków centralnych, Annales Universitatis Mariae Curie-Skłodowska, sectio H - Oeconomia, Vol. 51, No 6

Ben Bernanke (2016), What tools does the Fed have left? Part 1: Negative interest rates, „Brookings Institution”, 18 marca

Bernanke B.S. (2012), Monetary Policy since the Onset of the Crisis, August 31, https://www.federalreserve.gov/newsevents/speech/bernanke20120831a.htm

Dembinski P. H. (2017) Etyka i odpowiedzialność w świecie finansów, Wydawnictwo Studio Emka, Warszawa

Dudkiewicz B. (2016) Europejski Bank Centralny i nadzór finansowy w Unii Europejskiej a stabilność finansowa, CeDeWu.Pl, Warszawa

EBC (2017) Raport Roczny - Roczne sprawozdanie finansowe, www.nbp.pl/publikacje/publikacje_ecb/ar2017.pl.pdf

EBC (2018), The impact of the corporate sector purchase program on corporate bond markets and the financing of euro area non-financial corporations, https://www.ecb.europa.eu/pub/pdf/other/ecb.ebart201803_02.en.pdf

EBC (2017a), The ECB's corporate sector purchase programme: its implementation and impact; https://www.ecb.europa.eu/pub/pdf/other/ebbox201704_02.en.pdf

${ }^{7}$ Chodzi m. in. o następujący zapis: „Głównym instrumentem służącym realizacji celu operacyjnego polityki pieniężnej NBP są operacje otwartego rynku. Stosując je, NBP oddziałuje na warunki płynnościowe w sektorze bankowym w sposób umożliwiający kształtowanie się stawki POLONIA w pobliżu stopy referencyjnej NBP. (...) Operacje strukturalne mogą zostać przeprowadzone w celu długoterminowej zmiany struktury płynności w sektorze bankowym. Gdyby wystapiła taka konieczność, bank centralny może przeprowadzić następujące operacje strukturalne: emisję obligacji, zakup oraz sprzedaż papierów wartościowych na rynku wtórnym". 
Glapiński A. (2019) Powrót głównych banków centralnych do łagodzenia polityki pieniężnej, Bank 11 Goodhart Ch. A. E., Ashworth, J. P. (2012), QE: a successful start may be running into diminishing returns, Oxford Review of Economic Policy, Volume 28, Issue 4, 10 December, https://doi.org/10.1093/oxrep/grs034

Grostal i in. (2016), Alternatywne strategie polityki pieniężnej, NBP, Warszawa

Narodowy Bank Polski. Rada Polityki Pieniężnej, Założenia Polityki Pieniężnej na 2020 rok, https://www.nbp.pl/polityka_pieniezna/dokumenty/zalozenia/zalozenia_pp_2020.pdf

NBP (2018a), Zastosowanie niestandardowych działań przez Narodowy Bank Polski, Warszawa NBP (2018), Założenia Polityki Pieniężnej na rok 2019 www.nbp.pl/polityka_pieniezna/dokument y/zalozenia/zalozenia_pp_2019.pdf

NBP (2018b) Raport o inflacji, listopad, www.nbp.pl/polityka_pieniezna/dokumenty/raport_o_infl acji/raport_listopad_2018.pdf

Protokół (Nr 4) w sprawie Statutu Europejskiego Systemu Banków Centralnych i Europejskiego Banku Centralnego (Dz. Urz. UE C 326/230).

Roubini N., Mihm S. (2010), Crisis Economics: A Crash Course in the Future of Finanse, The Penguin Press, New York

Stiglitz J. B. (2012), Macroeconomics, Monetary Policy, and the Crisis [w:] Blanchard O., Romer D., Spencer M., Stiglitz J. (red.), In the Wake of the Crisis: Leading Economists Reassess Economic Policy, MIT Press, Cambridge

Taylor J. B. (2012), Monetary Policy Rules Work and Discretion Doesn't: A Tale of Two Eras, Journal of Money, Credit and Banking Lecture, March

Traktat o Funkcjonowaniu Unii Europejskiej (Dz. Urz. UE C 326/47)

\section{Summary}

This article presents the underlying legal and economic bases of so-called quantitative easing (QE) in the monetary policy of the Eurosystem. Large asset purchase programs and other intervention purchases of securities are discussed, and the risks of such policies for the long-term stability of the financial system are also addressed. It is noted that the non-standard financial instruments which are used in the Eurozone require close monitoring by Polish government financial institutions. This would help Poland access the full range of financial instruments that could be used to neutralize any unfavorable developments in the national financial sector and in the Polish economy which might occur in a global economic crisis. The research is based on analysis of European Central Bank documents and analytical studies of the Polish National Bank concerning non-standard instruments of financial policy.

Keywords: central bank, quantitative easing, large scale asset purchase programs

JEL Codes: G01, G21, G28, H12

Informacja o autorze:

Prof. Dr hab. Grażyna Ancyparowicz

Narodowy Bank Polski, Rada Polityki Pieniężnej

Górnośląska Wyższa Szkoła Handlowa

im. Wojciecha Korfantego w Katowicach

e-mail: sekretariat.rpp@nbp.pl

ORCID: 0000-0003-0196-7873 